\title{
A Teaching Model of Polynomial Functions' Learning Outcomes According to the System Approach for High School Students
}

\author{
Ahmad A.S. Tabieh* \\ Middle East University, Amman, Jordan \\ Faculty of Educational Secince
}

\begin{abstract}
This study aims at designing a model for teaching polynomial functions' learning outcomes based on the system approach (LOSA Model). The model includes procedural mechanisms for implementing each of its parts, yielding the model's outputs, i.e. the tools needed to use the model in teaching high school students. The study consists of three phases: designing the LOSA Model, development of the procedural mechanism of the LOSA model, and formulating the necessary outputs needed to use the model in teaching. This study provides a model for teaching the learning outcomes of polynomial functions, consisting of six domains: the mathematical content; the equipment; teaching methods; evaluation methods; the students; and the teacher. In each domain, the inputs were processed to produce the required outputs through a procedural method based on the system approach. In addition, the study provides an electronic procedural guide that shows precisely how to use each and every constituent of the model. It also provides the outputs of the model which are its usable tools as a teaching model. These outputs are the learning outcomes and their prerequisites; the mathematical content of polynomial functions; the supporting electronic content on Blackboard; the initial, formative, and summative evaluation tools; the mechanisms for preparing the equipment; the teaching methods; and the training methods that qualify the students and teachers to work with the model. The study was applied to a cluster sample of 138 experts in education and mathematics, and the methodology employed the quantitative and qualitative research.
\end{abstract}

Keywords: Teaching Model; Learning Outcomes; System Approach; Polynomial Function; High School

\section{Introduction}

Learning mathematics helps students acquire the necessary tools for tackling the daily problems they face in various domains of life (Amalia, Surya, \& Syahputra,

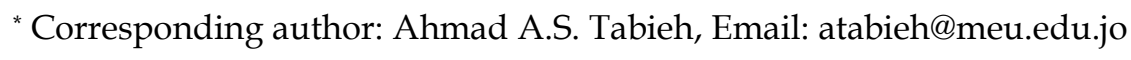


2017). Consequently, it has been increasingly important and has been stressed on the highest pedagogical levels (Eviyanti, Surya, Syahputra, \& Simbolon, 2017). The biggest challenge of learning mathematics is perhaps the fact that students have their own idiosyncrasies for thinking and processing when dealing with mathematical concepts (Curto Prieto, Orcos Palma, Blázquez Tobías, \& León, 2019). This can distract students from achieving the learning goals, which causes them to feel frustrated and bored with learning mathematics thinking that it requires special capabilities not attainable by everyone (Clements, Fuson, \& Sarama, 2017; Tan, 2017).

To face the challenge of learning mathematics, there has been a growing tendency to focus on students as the center of the learning process by identifying their capabilities and inclinations as inputs that undergo processing to achieve optimum learning results (Stelmach, Adams, \& Brandon, 2019). Such successful learning depends greatly on determining learning outcomes, which were defined by Adam (2006) and Gudeva, Dimova, Daskalovska, \& Trajkova (2012) as the written statements that identify what a learner is expected to achieve by the end of a unit, course, or an educational stage. Consequently, there has been a spreading international movement towards structuring courses based on learning outcomes (Darling-Hammond, 2017). For example, level-three courses in European higher education institutions are being redesigned in a way that reflects the extent of achieving learning outcomes (Alexandrov \& Sancho, 2017). Another example would be the establishment of the National Council of the Teachers of Mathematics, NCTM, which outlined the general principle and standards of learning outcomes in all fields of mathematics (Naja, 2018; Wilson, 2020). It is worth noting here that learning outcomes represent a more modern and inclusive model. While the traditional approach views inputs as the content, learning outcomes centralize students in the learning/teaching process highlighting outputs as an indicator of students' competence (Isdale, Reddy, Juan, \& Arends, 2018; Rothaermel, 2016), and providing teachers with insight into their students' level (Oudman, van de Pol, Bakker, Moerbeek, \& van Gog, 2018).

The argument above necessitates designing a model for teaching learning outcomes in a systematic approach that centralizes students in the learning process and utilizes their inputs to achieve the outputs, i.e. learning outcomes, through processing while at the same time enabling teachers to evaluate their students. The researcher of this study, therefore, employed the system approach for designing such a model. Barkley \& Major (2020) defines the system approach as an analytical method which organizes the parts in a system whereby these parts consolidate, each according to its function, to achieve the goals set for a certain task.

The researcher applied this model to the polynomial functions' unit of the College Algebra course for high school-level / pre-university students as it is the only compulsory mathematics course for all students at all universities within the study's community. In addition, according to the records of the previous academic year, the students scored lowest in polynomial function questions, reflecting difficulty in comprehending the polynomial functions unit of the 
course. Furthermore, the researcher ensured that the learning outcomes be created according to the standards of the NCTM so that this model for teaching learning outcomes based on the system approach is internationally applicable.

\section{Background}

The literature related to the idea of this research can be reviewed under three major fields. Teaching models in general and teaching models in mathematics are reviewed first. Then, the review covers the concept of learning outcomes in mathematics and their relatedness to teaching models in mathematics. Finally, the system approach is discussed as a tool for designing a teaching model in mathematics that is based on learning outcomes.

\subsection{Teaching Models in Mathematics}

A teaching model is a design for teaching that describes the processes which identify and produce educational environments that prompt students to interact in a way that creates a specific change in their behavior (Sinha, 2018). This definition is in keeping with the perception of Hofer \& Harris (2019) for a teaching model as a plan or pattern that can be used to structure a course, design content, and create an instructional guide for the classroom. In this context, the classroom is viewed as an interactive environment between students and teachers; an environment that allows the exchange of knowledge which ultimately leads to a better educational system (Korhonen, Ruhalahti, \& Veermans, 2019; Lamb, Annetta, Firestone, \& Etopio, 2018).

DuPlass (2006) classifies teaching models into five types, the first of which is "disposition modeling." Disposition modeling is based on students and teachers sharing ways of thinking, and it requires a creative teacher who is able to identify successful strategies for this model. In the second type, "task and performance modeling," a teacher highlights the tasks in which students are expected to be initiative, which makes them feel at ease with undertaking new tasks. The third type, "meta cognitive modeling," foregrounds the importance of the way of thinking by focusing on interpreting information and analyzing statements to arrive at results for what has been learned. In "modeling as scaffolding technique," Webb, Massey, Goggans, \& Flajole (2019) stress the teacher's responsibility to identify students' role in the learning process. This entails that a teacher, on multiple occasions, lay out tasks for students to do while helping the students who face difficulties. Finally, in "student-centered modeling," a teacher helps students identify the learning outcomes expected of them allowing the teacher to utilize the students with knowledge of the learning outcomes in question to help their classmates.

One of the most prominent teaching models for learning outcomes in mathematics was designed by Sari \& Surya (2017) in which they analyzed the learning outcomes observed from students' responses to mathematical problems. These responses, which provide tools for teaching mathematics, were classified into five levels. Level one is characterized by impulsiveness where the responses bear no direct relevance to the concepts required to solve the problem, and the student makes no discernible connection between these concepts 
(Hasibuan, Saragih, \& Amry, 2018). In level two, the responses show a partial possession of the concepts without fully grasping the relation between them and how they should be connected to achieve the solution. In level three, the student shows complete possession of the concepts; however, connecting these concepts to get to the solution is still somewhat lacking. The responses in level four show profound understanding of the relational connection between the concepts and an appreciation of how these concepts interact to deliver the solution. Finally, level five is marked by a high degree of confidence whereby the student transcends the mastery of the concepts and their relations to the point where he/ she tries to impart knowledge onto other students.

\subsection{Learning Outcomes in Mathematics}

Learning outcomes are defined as the statements that identify what a learner is expected to comprehend, know, or perform after the completion of a learning process (Kizilcec, Pérez-Sanagustín, \& Maldonado, 2017; Murtonen, Gruber, \& Lehtinen, 2017). In addition to specifying what a student is expected to perform, well-written learning outcomes must be observable, measurable, and achievable within the time limit and available resources (Tractenberg, Lindvall, Attwood, \& Via, 2020). As for the domains of learning outcomes, they were outlined by Bloom (1956) as the cognitive, affective, and psychomotor domains. The cognitive domain involves intellectual processes such as comprehension, analysis, and evaluation while the affective domain covers inclinations, feelings, and values such as appreciation and tolerance. On the other hand, physical activities, such as assembling and dismantling, fall under the umbrella of learning outcomes of the psychomotor domain.

It is important to note that in order for most mathematical concepts to be acquired, there has to be graduality of mental processing. This means that mathematical concepts have to be divided into levels that are suitable for each learning stage, starting from basic levels and culminating in the acquisition of these concepts by the end of the last learning stage. This graduality allows the retention of information for a long time which is essential to the acquisition of mathematical concepts. Ross, Bruderle, \& Meakim (2015) points out that learning outcomes enhance basic understanding and develop the skills which improve retention, leading eventually to the internalization of these concepts. As a result, the NCTM emphasizes that learning outcomes be logically ordered in a way that reflects the priority of learning each mathematical concept.

\subsection{System Approach in Mathematics}

The system approach is presented in education as an approach for managing, controlling, and improving educational processes and outcomes (Taylor, Oberle, Durlak, \& Weissberg, 2017). This approach is built on the concept of the system which is defined by Ackoff (1971) as a group of interrelated and coherent elements that integrate to form a unified whole. Therefore, viewing the learning/teaching process as a unified system of integrated elements (such as the students, the teachers, the content, the facilities, etc.) improves its effectiveness compared to each element functioning independently. 
One of the applications of the system approach in teaching is that of Mat, Yassin, Ishak, Mohammad, \& Pandaragan (2012). In this model, the learning/teaching process starts, before the beginning of teaching, with preparing inputs which include the content, lessons, teachers, facilities, and other resources. In the next stage, the activities that students do while learning are covered. Finally, the learning outcomes are achieved in the form of developed skills while allowing students to give their opinions and feedback about their performance. Another application of the system approach in learning is the model of Gupta \& Gupta (2013) which consists of several steps, namely analysis, design, development, execution, and evaluation.

The importance of the system approach can be seen from different angles. It perceives of the learning/teaching process as a whole rather than individual parts. It also serves as a systematic educational framework that facilitates decision making. In addition, it fully utilizes educational resources; offers an evaluation system that leads to immediate feedback; and improves teacher training programs (Rodríguez, Pérez, Cueva, \& Torres, 2017). Another point in favor of the system approach is the fact that the mathematics learning/teaching process involves several elements such as students, teachers, content, and other resources. This entails a system that unifies and processes these elements to attain an effective learning/teaching process. Employing the system approach, therefore, is ideal for achieving high quality in learning and teaching mathematics.

As for mathematical content, it is essential to shape it based on the system approach for a number of reasons. First, mathematical principles and concepts are structural in nature; they integrate to form areas of mathematics. Moreover, they are sequential in the sense that many of these concepts function as the corner stone for subsequent ones. Graduality is another characteristic of mathematical concepts. Each concept requires different levels of thinking to be grasped which means it needs to be studied in multiple stages with varying levels, starting from basic and concluding in the acquisition of the concept.

Narrowing the argument to the polynomial functions content, the researcher of this study chose this content as it is a mathematical field that lends itself perfectly to the system approach and because functions are an important tool in building mathematical models (Kitchen \& Berk, 2016). This applicability of the system approach to functions is corroborated by the NCTM as it specifies that functions at the school stage represent numerical inputs and outputs which are expressed algebraically and that the functions' processes represent the calculations which transform the inputs to outputs. The NCTM also points that functions enable checking for correct answers which in turn represents the feedback in the system. This input-process-output approach to functions establishes relevance to real life applications. From this point of view, the content can serve as a thinking framework that enables a learner to determine their inputs and process them to arrive at the outputs. It also enables verifying these outputs and accordingly improving or fixing them. 


\section{Study Objectives}

The study's primary objective is designing a model for teaching polynomial functions' learning outcomes based on the system approach (LOSA Model). The model includes procedural mechanisms for implementing each of its parts, yielding the model's outputs, i.e. the tools needed to use the model in teaching high school-level students. The study's secondary objectives are the following:

1- Designing a teaching model for polynomial functions' learning outcomes based on the system approach (LOAS Model) used for teaching the polynomial functions unit for high school-level students.

2- Developing the implementable procedural mechanisms of the LOSA Model which lead to its outputs.

3- Creating the LOSA Model's outputs (the tools that makes it usable in teaching) resulting from implementing the procedural mechanisms.

\section{Research Design}

This study represents the first part of a project for producing and evaluating a teaching model of learning outcomes based on the system approach. This project consists of four phases, three of which are in this first part, namely design, development, and pre-implementing. These three phases were all implemented during the second semester of the 2018-2019 academic year. The fourth phase of this project was the implementation and evaluation phase which will take place in the second part of the project executed in the second semester of the 2019/2020 academic year. Figure 1 below describes the study phases, the study's methodology, and the data collection tools.

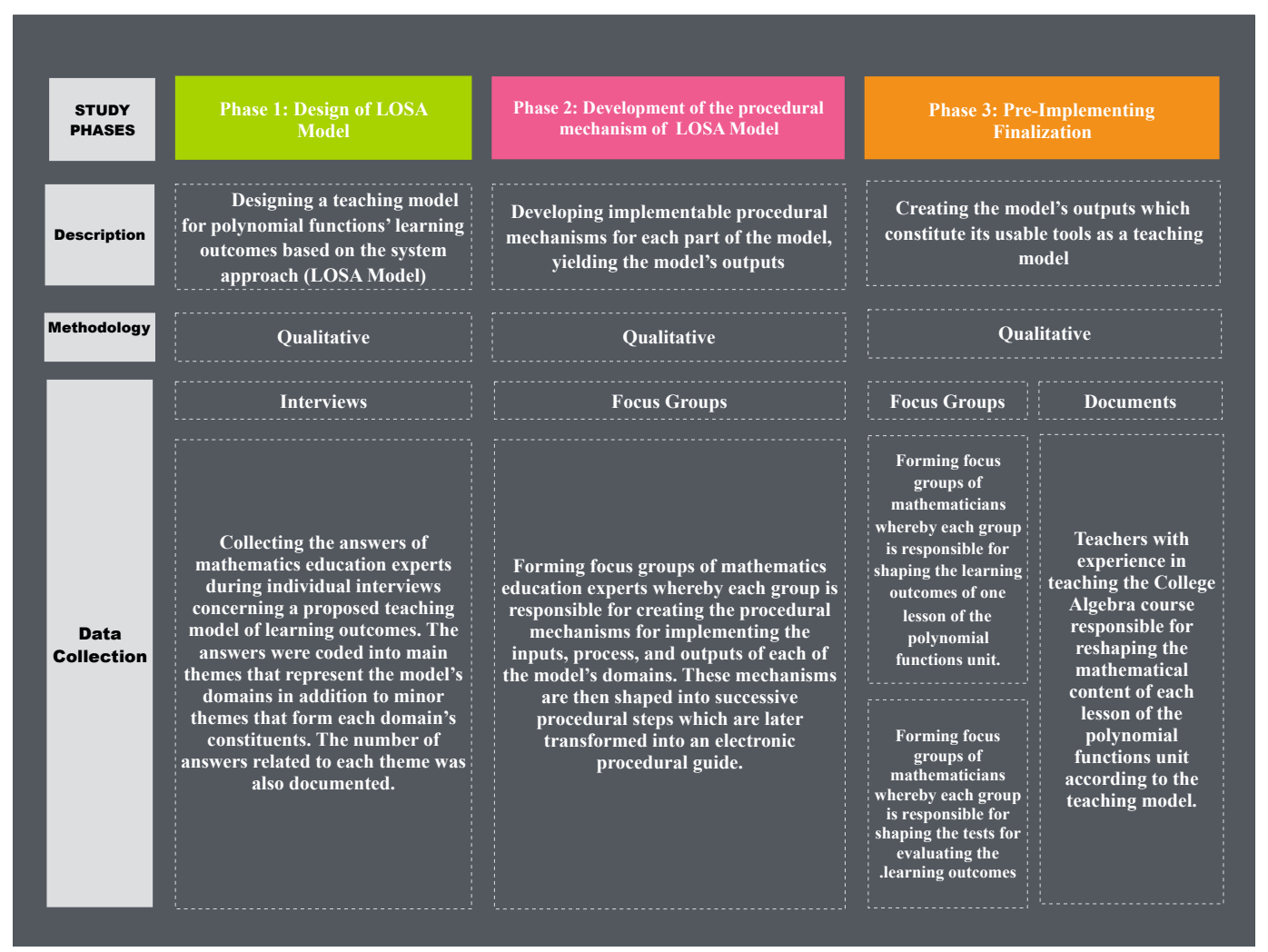

Figure 1: Study Phases, Methodology, and Data Collection Tools for Each Phase 


\section{Participants}

This study was implemented in three Jordanian universities: The University of Jordan, Middle East University, and Amman Arab University. These universities were chosen because of their proximity to each other and because the researcher is a faculty member at one of them, Middle East University. The study participants are faculty members of these universities with MS's and PhD's in mathematics, mathematics education, education technology, and information technology. The researcher formed a cluster sample (138) for this study, and Table 1 below shows the distribution of the participants in the study sample to the study phases based on their specialties and the phases in which they took part.

Table 1: Distribution of Study Sample to Study phases

\begin{tabular}{|c|c|c|c|l|c|}
\hline Community & Sample & Specialize & $\begin{array}{l}\text { Designing } \\
\text { the LOSA } \\
\text { Model } \\
\text { of the } \\
\text { procedural } \\
\text { mechanism } \\
\text { of the LOSA } \\
\text { model }\end{array}$ & $\begin{array}{l}\text { Formulating } \\
\text { the necessary } \\
\text { outputs needed } \\
\text { to use the } \\
\text { model in } \\
\text { teaching }\end{array}$ \\
\hline 84 & 43 & $\begin{array}{l}\text { Educational } \\
\text { Technology }\end{array}$ & & $\checkmark$ & $\checkmark$ \\
\hline 97 & 50 & $\begin{array}{c}\text { Mathematic } \\
\text { al } \\
\text { Education } \\
\text { (Experts) }\end{array}$ & $\checkmark$ & $\checkmark$ & \\
\hline 31 & 16 & $\begin{array}{c}\text { Mathematic } \\
\text { s teacher }\end{array}$ & & $\checkmark$ \\
\hline 89 & 25 & $\begin{array}{c}\text { Mathematic } \\
\text { ians }\end{array}$ & $\begin{array}{l}\text { Information } \\
\text { Technology }\end{array}$ & & $\checkmark$ \\
\hline
\end{tabular}

\section{Method}

The method used in this study was carefully designed based on the study's three phases.

\subsection{Phase One: Designing a Model for Polynomial Functions' Learning Outcomes Based on the System Approach (LOSA Model)}

The researcher conducted individual interviews for fifty experts from the study sample specialized in mathematics curriculum and teaching methods to collect their responses to three open-ended questions about the inputs, processes, and outputs required for creating a model for teaching polynomial functions based on the learning outcomes. Within each of the model's constituents (the inputs, processes, and outputs), the responses were coded into major and minor themes, and the number of responses for each theme was recorded. Based on the coded main themes, the researcher, with the help of some experts, induced the elements of the learning/teaching process as covered by the responses. These 
elements were named the model's domains; they are the mathematical content, the equipment, the teaching methods, the evaluation methods, the students, and the teachers. The experts were then asked to order the six domains according to what is best for the model's design. Based on the experts' responses, the major and minor themes were reordered as they will appear in the model whereby the inputs, processes, and outputs of each domain will include their major and minor themes.

Next, the model, in its new format, was presented to a new committee from the experts to get their feedback. The committee pointed out that the responses under the inputs of each domain include some themes which, in and of themselves, are preliminary outputs other than the final outputs at the end of each domain. For example, in the mathematical content domain, the theme of 'learning outcomes and their prerequisites' constitutes a preliminary output which will undergo processing to yield the final output, i.e. the mathematical material of polynomial functions. Since any output, whether preliminary or final, results from a process, the committee recommended creating an internal system of (inputs, processes, and outputs) for the inputs alone. The researcher, with the help of the committee, reclassified the themes under the inputs into preliminary inputs, processes, and outputs. This dynamic is shown in Figures 2.1 and 2.2 below.

The committee also remarked that the model's domains, with their final outputs, are in fact the tools necessary for using the model in teaching which requires a work plan for the model that consists of two systematic and successive stages. The first stage would be the designing of the model which takes place before teaching. The second stage would be the implementing and evaluating stage which coincides with the beginning and completion of teaching whereby the model's final outputs in all domains serve as the inputs of this stage. These inputs would eventually culminate into students who acquired the learning outcomes of polynomial functions as well as teachers who are qualified to teach polynomial functions according to the model. Figure 2 below illustrates the model in its final configuration.

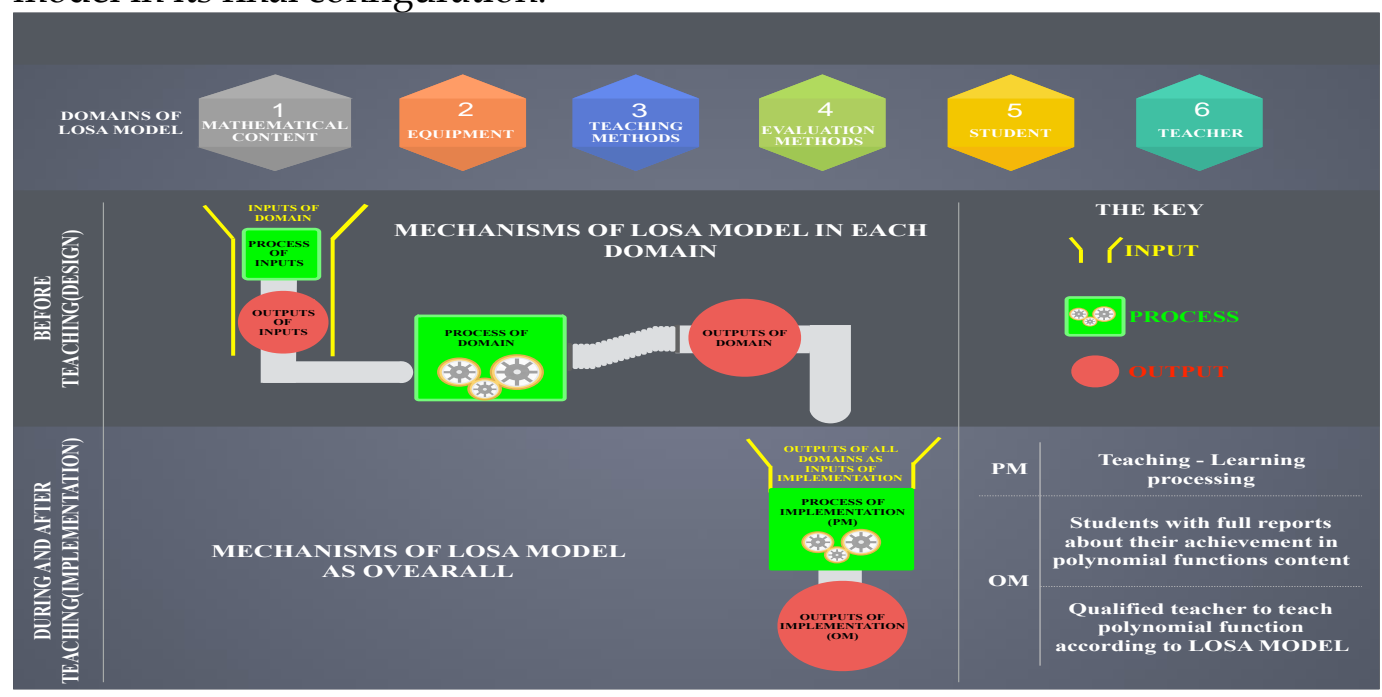

Figure 2: LOSA Model 


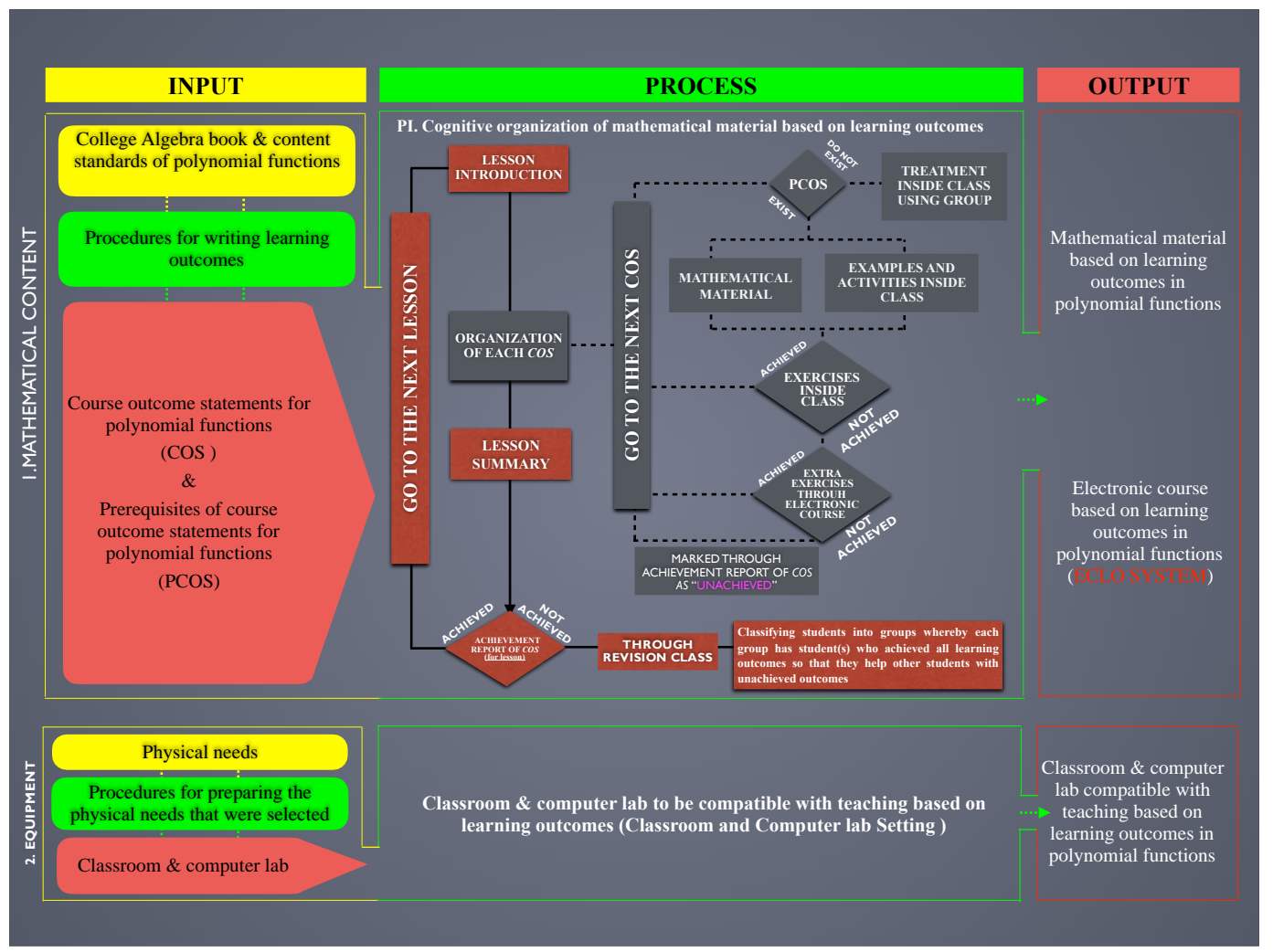

Figure 2.1: LOSA Model for each Domain, Part One

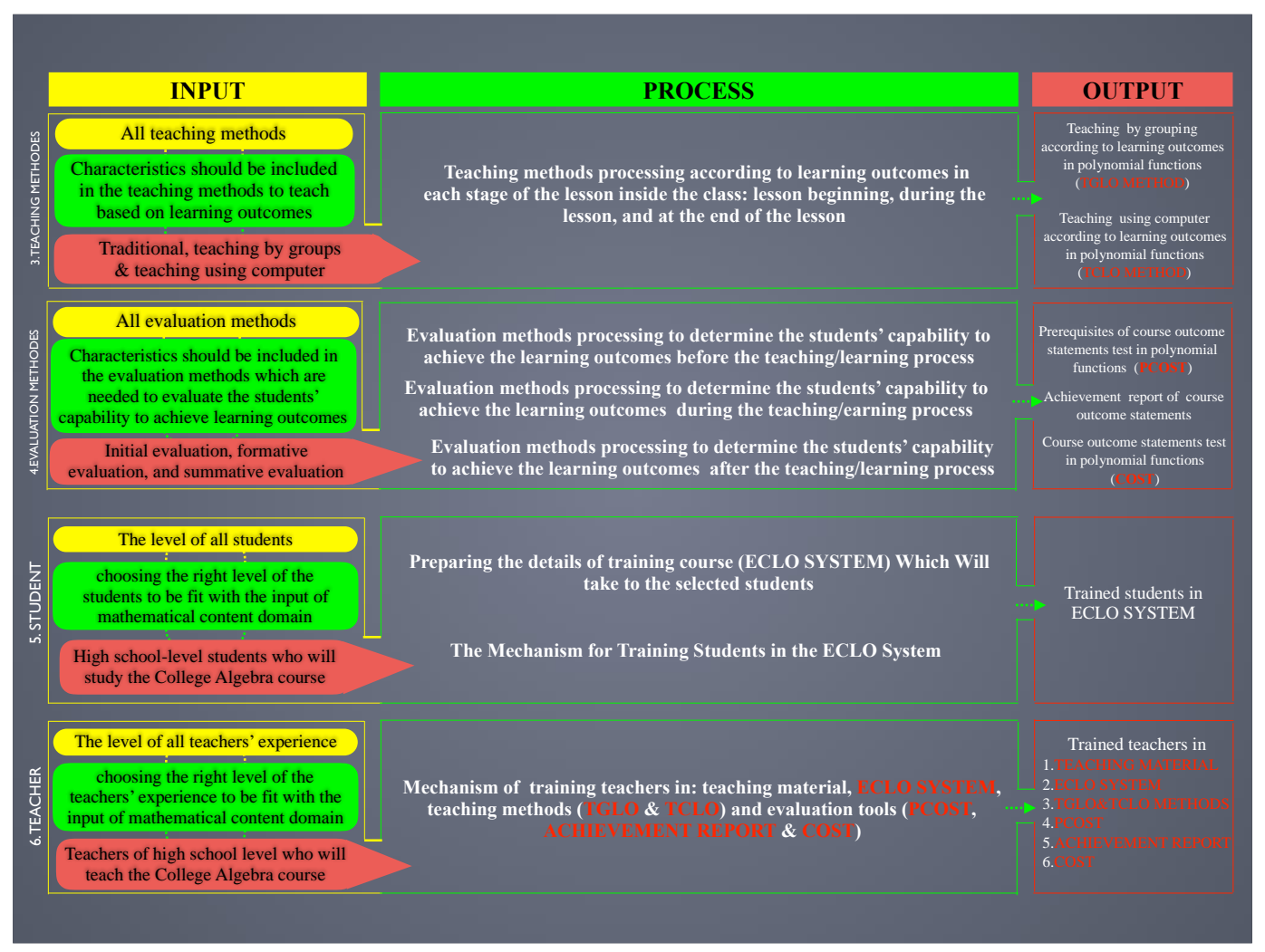

Figure 2.2: LOSA Model for each Domain, Part Two 


\subsection{Phase Two: Developing the Implementable Procedural Mechanisms of the} LOSA Model's Constituents for each Domain to Yield Its Outputs

The researcher divided the mathematics education experts into six focus groups whereby each group was responsible for creating the implementable procedural mechanisms for one of the model's six domains. Each group was asked to write the implementable procedural steps required to process the inputs of each domain to yield its outputs. The domains of the mathematical content, the teaching methods, the evaluation methods, and the teachers were assigned to a group of ten male experts while the domains of the equipment and the students were assigned to a group of five female experts. The assignment of these experts to these groups was based on each expert's specialties and relevant experience. Each group's contribution (shown in Appendix-I) was shaped into the final form of the procedural mechanisms of the model's domains before returning them to the group for further feedback and suggestions.

In the next stage, after trying several online form builders and consulting information technology experts, the researcher transformed the implementable procedural mechanisms into an electronic procedural guide using the online form builder (https://www.cognitoforms.com). Once the electronic guide was completed, forty-three educational technology experts were given a week-long access to test the guide's procedural validity and inclusiveness of all constituents, and the experts' feedback was utilized in making the necessary modifications. Finally, the experts were asked to evaluate the electronic guide by responding to a special evaluation form of (Singh, 2003), consisting of twentyfive items that covered eight features of the guide (purpose, researcher's information, accuracy, subjectivity, consistency, inclusiveness, technicalities, and general characteristics). The experts rated each of the eight features on a scale of $0-10$ whereby 0 is "unachieved" and 10 is "fully achieved." The following is the link to the electronic guide (https://www.cognitoforms.com/ElectronicForms1/LOSAMODEL).

6.3 Phase Three: Preparing to Implement the LOSA Model to Produce Its Outputs Which Are Considered Its Usable Tools as a Teaching Model

Relying on the electronic procedural guide, the researcher identified the model's outputs to be prepared, namely polynomial functions learning outcomes and their prerequisites; the mathematical and electronic content; teaching methods; evaluation methods; and training. These outputs have been included in the electronic procedural guide which can be consulted when using the LOSA Model in teaching.

\subsubsection{Learning Outcomes and Their Prerequisites}

Based on the recommendations of mathematicians and mathematics education experts, the researcher chose the most suitable basic algebra textbook and identified the polynomial functions unit as the focus. Next, three standards of polynomial functions were taken from the recommendations of the National Council for the Teachers of Mathematics (NCTM), namely interpreting functions; building functions; linear, quadratic and polynomial functions. The mathematics experts of the study sample were then asked to derive and create the learning outcomes for each lesson of the polynomial function's unit of the chosen 
textbook according to a form prepared by the researcher for creating learning outcomes. The experts were divided into three groups with each group assigned the learning outcomes of one lesson. The groups' responses were used to create the learning outcomes that were then returned to the mathematics education experts to verify their cognitive sequence; determine the standard for mathematical content for each outcome; and identify the prerequisite(s) for each outcome. The learning outcomes were revised into their final form shown in Table 2 below.

Table 2: The (COS) and (PCOS) according to the Mathematical Content Standards of Functions (MCS-F)

\begin{tabular}{|c|c|c|}
\hline MCS-F*** & $\mathrm{COS}^{*}$ & PCOS** \\
\hline $\begin{array}{l}\text { F-IF Interpreting } \\
\text { Functions }\end{array}$ & $\begin{array}{l}\text { The ability to determine the } \\
\text { slope of horizontal, vertical, } \\
\text { and any line passing through } \\
\text { two points } \\
\text { Defining X and Y intercepts for } \\
\text { any line } \\
\text { Using the graph of any linear } \\
\text { function to define the features } \\
x \text { and } y \text { intercepts as well as } \\
\text { slope } \\
\text { Defining the basic features of } \\
\text { the quadratic function: vertex, } \\
\text { minimum-maximum value and } \\
\text { equation of symmetry } \\
\text { Defining the basic features of } \\
\text { polynomial functions } \\
\text { Determining the type of } \\
\text { polynomial graph }\end{array}$ & $\begin{array}{l}\text { Understanding the } \\
\text { concepts of: } O \text {, } \\
\text { undefined } \\
\text { Determining a point } \\
\text { that lies on any given } \\
\text { linear equation or on its } \\
\text { graph } \\
\text { Solving any linear } \\
\text { equation with one } \\
\text { variable } \\
\text { Solving any quadratic } \\
\text { equation } \\
\mid a x^{2}+b x+c=0 \text {, where } \\
\mid a \neq 0\end{array}$ \\
\hline $\begin{array}{l}\text { F-BF Building } \\
\text { Function }\end{array}$ & $\begin{array}{l}\text { The ability to construct the } \\
\text { equation of the line under given } \\
\text { conditions } \\
\text { The knowledge of the quadratic } \\
\text { function forms: standard and } \\
\text { shifted } \\
\text { The ability to reconstruct any } \\
\text { quadratic functions from } \\
\text { standard to shifted or vice } \\
\text { versa } \\
\text { Using the graph of any } \\
\text { quadratic functions to build the }\end{array}$ & $\begin{array}{l}\text { Rewriting a given linear } \\
\text { equation with more } \\
\text { than one variable in } \\
\text { terms of one of its } \\
\text { variables } \\
\text { Writing X and Y- } \\
\text { intercepts as an ordered } \\
\text { pair } \\
\text { Understanding the } \\
\text { relationship between } \\
\text { parallel/perpendicular } \\
\text { lines } \\
\text { Applying the }\end{array}$ \\
\hline
\end{tabular}




\begin{tabular}{|c|c|c|}
\hline & $\begin{array}{l}\text { equation } \\
\text { Using the graph of any } \\
\text { polynomial function to } \\
\text { construct its equation }\end{array}$ & $\begin{array}{l}\text { completing square } \\
\text { technique to the } \\
\text { quadratic function } \\
\text { Defining increasing- } \\
\text { decreasing intervals for } \\
\text { any polynomial graphs } \\
\text { Defining the zeros of } \\
\text { any polynomial } \\
\text { equations written in } \\
\text { factored form } \\
\text { Constructing the poly } \\
\text { with integer coefficient } \\
\text { from real zeros degree }\end{array}$ \\
\hline $\begin{array}{l}\text { F-LE: Linear, } \\
\text { Quadratic, and } \\
\text { Polynomial Models }\end{array}$ & $\begin{array}{l}\text { The ability to design the graph } \\
\text { of linear model: constant, } \\
\text { vertical, and oblique } \\
\text { The ability to design the graph } \\
\text { of quadratic model } \\
\text { The ability to design the graph } \\
\text { of the polynomial model: } \\
f(x)=a x^{n}+b x^{n-1}+\cdots+c x^{0}\end{array}$ & $\begin{array}{l}\text { Using the table to graph } \\
\text { linear equation with } \\
\text { two variables } \\
\text { Using the table to } \\
\text { sketch the graph of any } \\
\text { non-linear equation } \\
\text { with two variables } \\
\text { Defining the degree } \\
\text { and substitute for any } \\
\text { factorable polynomial } \\
\text { Solving any factorable } \\
\text { polynomial equation }\end{array}$ \\
\hline
\end{tabular}

\subsubsection{The Mathematical Content}

The researcher divided the teachers of the study sample into four groups of four teachers. To write the mathematical content, each group was provided with the learning outcomes and their prerequisites; the standard for every outcome; the chosen algebra textbook; and the LOSA Model to follow its cognitive organization of the mathematical material. The groups were also given access to the electronic procedural guide to utilize its procedural steps related to writing the mathematical content. The first three groups were charged with writing the mathematical content for polynomial functions, with each group responsible for one of the three lessons, i.e. linear functions, quadratic functions, and polynomial functions of higher degree. The fourth group, which consisted of the most experienced teachers, had a supervisory role and revised the content written by the three groups to ensure its compatibility with the procedural guide. Finally, the mathematical content was presented to mathematics experts whose feedback was employed in modifying the content into its final form. The electronic procedural guide for the outputs of the first domain, the mathematical content, contains the mathematical material for the first lesson as an example. 
The researcher chose the content for polynomial functions because the students of the previous year scored lower in polynomial function questions than they did in any other area of the mathematical content of the course. Therefore, if the model proves effective in improving the students' performance in the unit they were worst at, this will give it greater credibility to be applied to other units. In addition, it was the experts' recommendation that the model be applied to the polynomial functions unit since it is taught in the spring semester of the academic year which coincides with the second part of this project when the model was intended to be implemented and evaluated.

\subsubsection{The Electronic Content}

The researcher provided the information technology specialists in the study sample with the mathematical content created by the teachers to build an electronic course on Blackboard with the help of the supervisory group of the most experienced teachers. The implementable mechanisms of the procedural guide related to the mathematical content domain were also utilized in creating the electronic course. After completion, the electronic course was tested and evaluated by information technology specialists to ensure it is operating properly. Finally, it was evaluated and reviewed by education technology experts whose feedback was taken into consideration to finalize the course.

The electronic course was created on Blackboard to supplement and reinforce the material given in class. This electronic course is accessible to the students from anywhere at any time, enabling them to navigate the material, the drills and exercises, as well as various tutorial videos related to the material. At the end of every class, the teacher logs the achieved and unachieved outcomes for each student which are later transferred to the electronic course. The electronic course, as a result, provides additional exercises, prepared by the teacher, assigned for certain learning outcomes and accessible only to the students who failed to achieve those outcomes. This feature offers another opportunity for the students to improve on what they could not achieve in class.

When it comes to feedback, the electronic course provides individual reports for each student showing their achieved and unachieved outcomes. It also contains a comprehensive report of the students achieved and unachieved outcomes (Achievement Report of COS) which is then used by the teacher to form study groups for a separate revision class.

The electronic system utilizes the discussion board feature of Blackboard as a means of achieving outcomes. On the discussion board, students are able to communicate with one another about their achieved and unachieved outcomes. This communication is intended to help the students who have unachieved outcomes engage in dialogue with their classmates who achieved those outcomes, ultimately resulting in achieving all outcomes.

\subsubsection{Classroom and Labs}

An administrative committee was formed to prepare the classrooms and labs in accordance with the procedural mechanisms of the second domain, the equipment. Enough classrooms and labs were designated and prepared to be used by the students of the LOSA Model in the spring semester of 2015/2016. In 
the labs, the electronic course was installed on each computer, and the classrooms were provided with the necessary equipment for implementing the model (chairs; whiteboards; hard copies of the mathematical content for each student and teacher; and learning outcomes achievement form for the teacher of each section). Then, the teachers of the study sample were assigned the sections they will be working with. Finally, some of the experts of the study sample were asked to evaluate the suitability and readiness of the classrooms and labs according to the implementable procedural guide.

\subsubsection{Teaching by Grouping according to Learning Outcomes (TGLO)}

The researcher conducted a discussion session with the experts to create a procedural guide for teaching by grouping inside the classroom. Depending on the procedural guide of the teaching methods domain, the general guidelines of teaching by grouping were established. The teaching by grouping method depends on the achievement report of COS whereby the students are sorted out in study groups for a separate revision class. The groups are created in such a way that the students of different achieved and unachieved outcomes are joined together. This means that in a group, each student with unachieved outcome(s) has another student who has already achieved the corresponding outcome(s) so that between them, all outcomes are achieved by the end of the revision class. During the revision class, the teacher hands out separate worksheets for each learning outcome containing various exercises related to that outcome. The students in a group work only on the sheet(s) of their unachieved outcome(s), and the teacher, meanwhile, checks the students' performance to ensure that all outcomes are achieved. Figure 3 below illustrates the mechanism of forming and using the study groups.

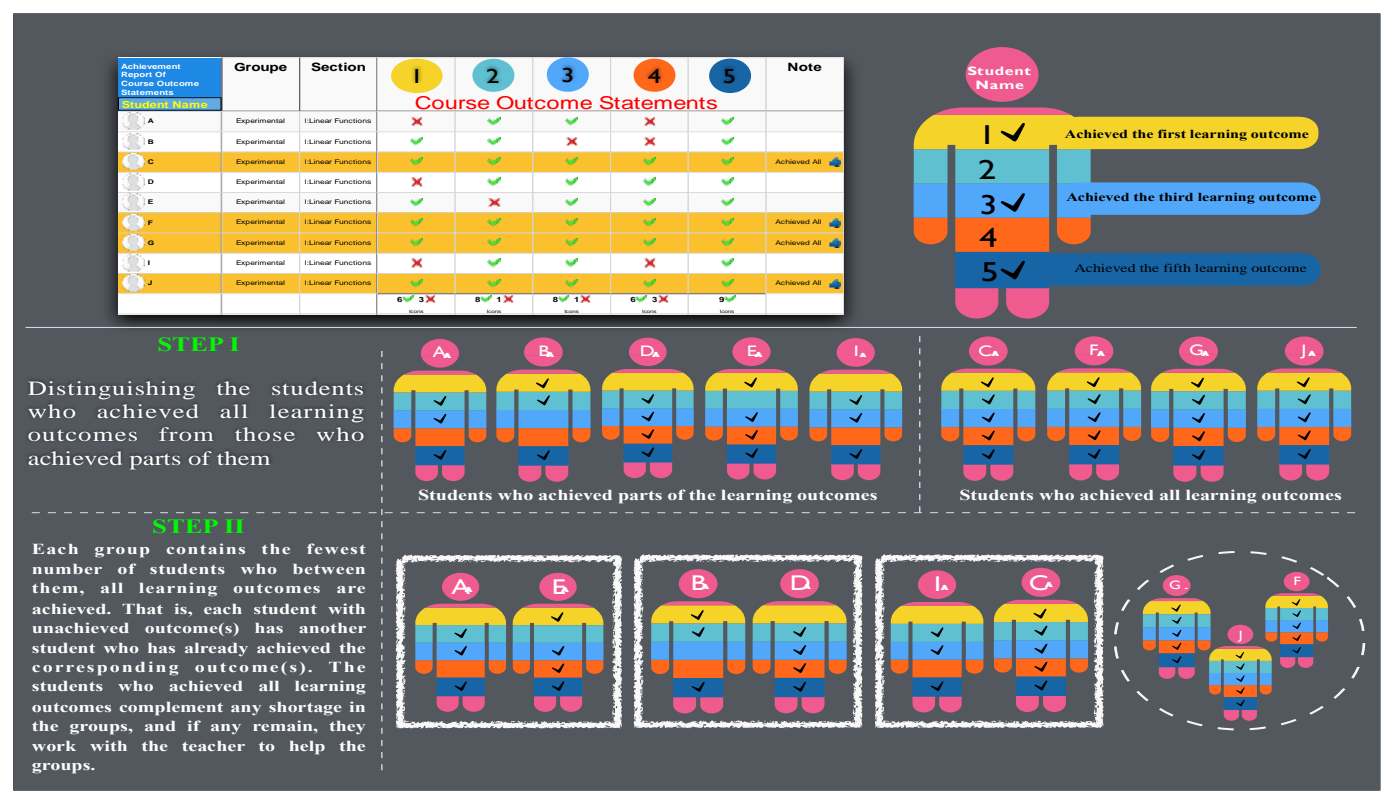

Figure 3: LOSA Model for each Domain, Part Two 


\subsubsection{Evaluation Methods}

The researcher divided the mathematics specialists into two groups responsible for creating three instruments:

Prerequisites of Course Outcome Statements Test (PCOST) which was written with its answers by the first group based on the prerequisites of Table 2 above. The second group revised the test into its final form with 17 one-mark-each, multiple choice questions covering all the prerequisites of the learning outcomes of polynomial functions. This test serves as an initial evaluation before the beginning of teaching in order to identify the extent to which the students possess the prerequisites and prior knowledge of each outcome. The results of this test function as a reference for the teacher to address the relevant shortcomings during class and to utilize the students who possess the prior knowledge of certain outcomes to help their classmates who lack this knowledge. This test is found in the electronic procedural guide of the fourth domain, the evaluation methods.

Course Outcome Statements Test (COST) which is the test that measures the extent to which the learning outcomes have been achieved after teaching. The test with its answers was written by the second group according to the learning outcomes in Table 2 above. It was revised by the first group into its final form of 14 one-mark-each, multiple choice questions. This test is also found in the electronic procedural guide of the fourth domain, the evaluation methods.

Achievement Report of Course Outcome Statements: this report is a type of formative evaluation which uses the results of the students in the exercises for each learning outcome to assess the extent to which each outcome has been achieved by every student. This report serves as a reference for each student about their performance in each outcome as well as a reference for the teacher who updates it on the electronic course on Blackboard after teaching each outcome.

The evaluation instruments above were revised by the experts to verify their comprehensiveness on two levels: first, whether each question in the tests comprehensively covers the learning outcome/prerequisite for which it was written and second, whether the tests are inclusive of all learning outcomes and their prerequisites. Then, the tests were applied to a pilot study of thirty students of the previous year's College Algebra course to verify their validity and reliability. The PCOST and the COST had a Cronbach's Alpha Coefficient of (0.79) indicating high reliability for both tests. As for content validity, the correlation coefficient for the standard of interpreting functions in all related questions of the Prerequisites of Course Outcome Statements Test (PCOST) and the Course Outcome Statements Test (COST) was 0.72. The correlation coefficient for the standard of building functions in all related questions of the PCOST and the COST was 0.74 and 0.72 respectively. The correlation coefficient for the standard of linear, quadratic, and polynomial functions in all related questions of the PCOST and the COST was 0.77 and 0.72 respectively. Finally, the correlation coefficient between the marks allocated for the three standards in the PCOST and the COST and the tests' overall mark was 0.77 and 0.83 
respectively. The above correlation coefficients indicate a reasonable level of correlation which indicates an acceptable level of validity.

\subsubsection{Training}

The teachers of the study sample were divided into four groups to be trained in four of the training axes that were deemed necessary, namely teaching the mathematical content; the electronic system; teaching methods; and evaluation methods. Four experts were designated as trainers, with each expert responsible for one of the training axes, and then assigned a group of teachers which they trained in one of these axes. Each expert was then provided with the learning outcomes and the training mechanisms found in the procedural guide under the teacher domain. Finally, the scheduling of each group's training was completed. After the four-day training was over, each teacher was asked to train his prospective students in how to use the electronic content. This training took place in the first week of the following semester (the second semester 2018/2019 academic year) so that both the teachers and the students are fully prepared to work with the teaching model.

\section{Findings}

Based on the method used, the study yielded both qualitative and quantitative results which are presented in Tables 3-10 below and discussed in detail.

\subsection{Qualitative Results}

Tables 3-8 below represent the responses of the experts to the open-ended questions designed to create the inputs, processes, and outputs for each of the model's domains. Table 9, on the other hand, shows the experts' responses to the most suitable order of the model's domains. In total, fifty experts responded.

Table 3: Thematic Content of Experts' Narratives on Designing the LOSA Model within the Mathematical Content Domain

\begin{tabular}{|c|c|c|c|}
\hline \multicolumn{2}{|c|}{ Category } & Subcategories & $\begin{array}{l}\text { No. of } \\
\text { narratives }\end{array}$ \\
\hline \multirow[t]{5}{*}{ Input } & College algebra book & No Subcategories & $33(66 \%)$ \\
\hline & $\begin{array}{ll}\text { International standards } & \text { of } \\
\text { polynomial functions content } & \end{array}$ & No Subcategories & $47(94 \%)$ \\
\hline & Writing learning outcomes criteria & No Subcategories & $35(70 \%)$ \\
\hline & $\begin{array}{lcr}\begin{array}{l}\text { Course } \\
\text { statements } \\
\text { functions }\end{array} & \begin{array}{c}\text { learning } \\
\text { for }\end{array} & \begin{array}{r}\text { outcome } \\
\text { polynomial }\end{array} \\
\end{array}$ & No Subcategories & $49(98 \%)$ \\
\hline & $\begin{array}{l}\text { Prerequisites of course outcome } \\
\text { statements for polynomial } \\
\text { functions }\end{array}$ & No Subcategories & $44(88 \%)$ \\
\hline \multirow[t]{7}{*}{ Process } & \multirow{3}{*}{$\begin{array}{l}\text { Organizations of course outcome } \\
\text { statements at lesson level }\end{array}$} & Introduction & $48(96 \%)$ \\
\hline & & Summary & $37(74 \%)$ \\
\hline & & Feedback & $39(78 \%)$ \\
\hline & \multirow[t]{4}{*}{$\begin{array}{l}\text { Organizations of Each course } \\
\text { outcome statements }\end{array}$} & \begin{tabular}{|l} 
Prerequisites of Learning \\
outcome
\end{tabular} & $38(76 \%)$ \\
\hline & & Learning Outcome Content & $49(98 \%)$ \\
\hline & & Class Activities(examples) & $41(82 \%)$ \\
\hline & & Class exercises & $40(80 \%)$ \\
\hline
\end{tabular}




\begin{tabular}{|l|l|l|l|}
\hline & \multicolumn{1}{|c|}{ Achievement feedback } & $42(84 \%)$ \\
\cline { 2 - 4 } Output & $\begin{array}{l}\text { New mathematical materials for } \\
\text { polynomial functions based on } \\
\text { Course outcome statements }\end{array}$ & No Subcategories & $46(92 \%)$ \\
\hline & $\begin{array}{l}\text { Supported Electronic course on } \\
\text { blackboard }\end{array}$ & No Subcategories & $31(76 \%)$ \\
\hline Domain Percentage & $82 \%$ \\
\hline
\end{tabular}

Note. The percentage $=($ No. of narratives $/ 50)$

Table 4: Thematic Content of Experts Narratives on Designing LOSA Model within the Equipment Domain

\begin{tabular}{|l|l|l|l|}
\hline Category & Subcategories & $\begin{array}{l}\text { No. of } \\
\text { narratives }\end{array}$ \\
\hline Input & Physical Needs & Detect Physical Needs & $50(100 \%)$ \\
\cline { 2 - 4 } & $\begin{array}{l}\text { Procedures of Preparing the } \\
\text { Physical Needs }\end{array}$ & No Subcategories & $44(88 \%)$ \\
\cline { 2 - 4 } & Classroom & No Subcategories & $30(60 \%)$ \\
\cline { 2 - 4 } & Computer lab & No Subcategories & $31(62 \%)$ \\
\hline Process & classroom setting & $\begin{array}{l}\text { Prepare classrooms to be } \\
\text { compatible with teaching } \\
\text { based on learning outcomes }\end{array}$ & $36(72 \%)$ \\
\cline { 2 - 5 } & computer lab setting & $\begin{array}{l}\text { Prepare computer labs to be } \\
\text { compatible with teaching } \\
\text { based on learning outcomes }\end{array}$ & $33(66 \%)$ \\
\hline Outputs & Classrooms ready to use & No Subcategories & $50(100 \%)$ \\
\cline { 2 - 5 } & computer labs ready to use & No Subcategories & $44(88 \%)$ \\
\hline Domain Percentage & & $80 \%$ \\
\hline
\end{tabular}

Note. The percentage $=($ No. of narratives $/ 50)$

Table 5: Thematic Content of Experts Narratives on Designing LOSA Model within the Teaching Methods Domain

\begin{tabular}{|c|c|c|c|}
\hline \multicolumn{2}{|c|}{ Category } & \multirow{2}{*}{$\begin{array}{l}\text { Subcategories } \\
\text { No Subcategories }\end{array}$} & \multirow{2}{*}{$\begin{array}{l}\text { No. of } \\
\text { narratives }\end{array}$} \\
\hline Input & $\begin{array}{l}\text { Characteristics should be } \\
\text { included in teaching methods } \\
\text { selected to teach based on course } \\
\text { outcome statements }\end{array}$ & & \\
\hline & Traditional Teaching & No Subcategories & $30(60 \%)$ \\
\hline & Teaching Using Groups & No Subcategories & $49(98 \%)$ \\
\hline & Teaching using computers & No Subcategories & $41(82 \%)$ \\
\hline \multirow[t]{2}{*}{ Process } & \multirow{2}{*}{$\begin{array}{l}\text { Teaching methods processing } \\
\text { according to learning outcomes in } \\
\text { each stage of the lesson inside the } \\
\text { classroom: lesson beginning, } \\
\text { during the lesson, and at the end } \\
\text { of the lesson }\end{array}$} & Teaching by grouping & $37(74 \%)$ \\
\hline & & Teaching using computer & $33(66 \%)$ \\
\hline Outputs & $\begin{array}{l}\text { Teaching by grouping according } \\
\text { to learning outcomes in }\end{array}$ & No Subcategories & $49(98 \%)$ \\
\hline
\end{tabular}




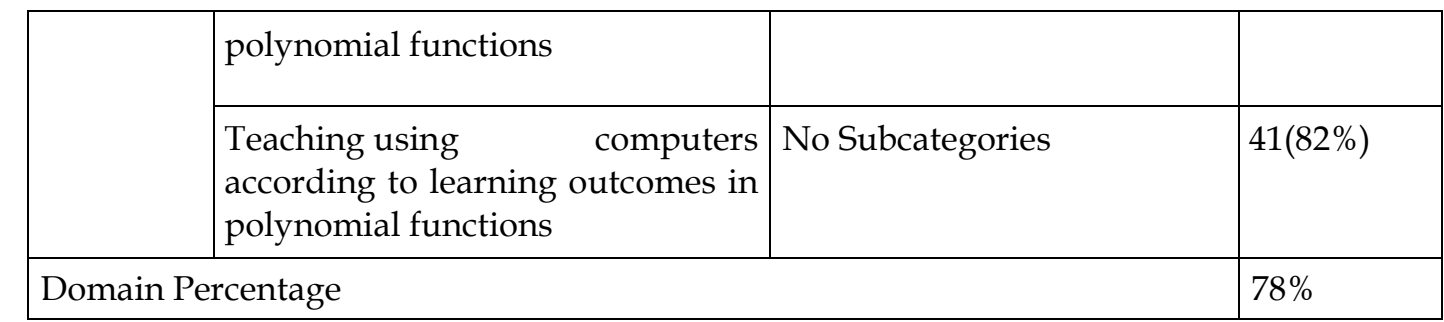

Note. The percentage $=($ No. of narratives $/ 50)$

Table 6: Thematic Content of Experts Narratives on Designing LOSA Model within the Evaluation Methods Domain

\begin{tabular}{|c|c|c|c|}
\hline \multicolumn{2}{|l|}{ Category } & \multirow{2}{*}{\begin{tabular}{|l|} 
Subcategories \\
No Subcategories
\end{tabular}} & \multirow{2}{*}{$\begin{array}{l}\begin{array}{l}\text { No. of } \\
\text { narratives }\end{array} \\
41(82 \%)\end{array}$} \\
\hline \multirow[t]{4}{*}{ Input } & $\begin{array}{l}\text { Characteristics should be included } \\
\text { in evaluation methods selected to } \\
\text { evaluate based on course outcome } \\
\text { statements }\end{array}$ & & \\
\hline & Initial Evaluation & \begin{tabular}{|l} 
evaluate student in the \\
Prerequisites
\end{tabular} & $40(80 \%)$ \\
\hline & Formative Evaluation & $\begin{array}{l}\text { evaluate student in each } \\
\text { Course } \\
\text { statements }\end{array}$ & $48(96 \%)$ \\
\hline & Summative evaluation & $\begin{array}{l}\text { evaluate the overall } \\
\text { achievement student after } \\
\text { learning all course } \\
\text { outcome statements }\end{array}$ & $50(100 \%)$ \\
\hline \multirow[t]{3}{*}{ Process } & \multirow{3}{*}{$\begin{array}{l}\text { Evaluation methods processing to } \\
\text { determine the students' capability } \\
\text { to achieve the learning outcomes }\end{array}$} & $\begin{array}{l}\text { before the } \\
\text { teaching/learning process }\end{array}$ & $33(66 \%)$ \\
\hline & & $\begin{array}{l}\text { during the } \\
\text { teaching/learning process }\end{array}$ & $39(78 \%)$ \\
\hline & & $\begin{array}{l}\text { after the teaching/learning } \\
\text { process }\end{array}$ & $36(72 \%)$ \\
\hline \multirow[t]{3}{*}{ Outputs } & $\begin{array}{l}\text { Prerequisites of Course outcome } \\
\text { statements test in polynomial } \\
\text { functions }\end{array}$ & No Subcategories & $38(76 \%)$ \\
\hline & 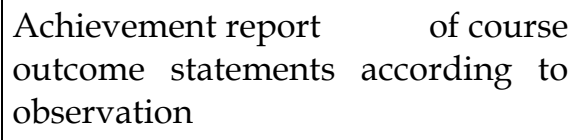 & No Subcategories & $49(98 \%)$ \\
\hline & $\begin{array}{l}\text { Course outcome statements test in } \\
\text { polynomial functions }\end{array}$ & No Subcategories & $50(100 \%)$ \\
\hline \multicolumn{3}{|c|}{ Domain Percentage } & $85 \%$ \\
\hline
\end{tabular}

Note. The percentage $=($ No. of narratives $/ 50)$ 
Table 7: Thematic Content of Experts Narratives on Designing LOSA Model within the Students Domain

\begin{tabular}{|c|c|c|c|}
\hline \multicolumn{2}{|l|}{ Category } & \multirow{2}{*}{\begin{tabular}{|l|} 
Subcategories \\
No Subcategories \\
\end{tabular}} & \multirow{2}{*}{$\begin{array}{l}\text { No. of } \\
\text { narratives }\end{array}$} \\
\hline Input & $\begin{array}{l}\text { choosing the right level of the students } \\
\text { to be fit with the input of mathematical } \\
\text { content domain }\end{array}$ & & \\
\hline & $\begin{array}{l}\text { High school-level student s who will } \\
\text { take the College Algebra course }\end{array}$ & No Subcategories & $48(96 \%)$ \\
\hline \multirow[t]{3}{*}{ Process } & $\begin{array}{l}\text { Identifying the training axes which will } \\
\text { be given to the selected students }\end{array}$ & $\begin{array}{l}\text { using the supporting } \\
\text { electronic course } \\
\text { (ECLO SYSTEM) }\end{array}$ & $31(62 \%)$ \\
\hline & $\begin{array}{l}\text { Preparing the details of the (ECLO } \\
\text { SYSTEM) training Which Will be given to } \\
\text { the selected students }\end{array}$ & No Subcategories & $31(62 \%)$ \\
\hline & $\begin{array}{l}\text { The mechanism for training students in } \\
\text { the supporting electronic course on } \\
\text { Blackboard }\end{array}$ & No Subcategories & $31(62 \%)$ \\
\hline Outputs & Trained students in & $\begin{array}{l}\text { The supporting } \\
\text { electronic course on } \\
\text { Blackboard }\end{array}$ & $36(72 \%)$ \\
\hline \multicolumn{3}{|c|}{ Domain Percentage } & $73 \%$ \\
\hline
\end{tabular}

Note. The percentage $=($ No. of narratives $/ 50)$

Table 8: Thematic Content of Experts narratives on Designing LOSA Model within the Teachers Domain

\begin{tabular}{|l|l|l|l|}
\hline Category & Subcategories & $\begin{array}{l}\text { No. of } \\
\text { narratives }\end{array}$ \\
\hline Input & $\begin{array}{l}\text { High school teacher level who will teach } \\
\text { college algebra course }\end{array}$ & No Subcategories & $48(96 \%)$ \\
\cline { 2 - 4 } & $\begin{array}{l}\text { choosing the teachers with the right } \\
\text { level of experience to fit the input of } \\
\text { mathematical content domain }\end{array}$ & No Subcategories & $42(84 \%)$ \\
\hline Process & \multirow{2}{*}{$\begin{array}{l}\text { Mechanisms of training workshop to } \\
\text { train teachers on }\end{array}$} & $\begin{array}{l}\text { Teaching material } \\
\text { blectronic course on learning } \\
\text { outcomes in } \\
\text { polynomial functions }\end{array}$ & $38(76 \%)$ \\
\cline { 3 - 5 } & & Teaching Methods & $33(66 \%)$ \\
\cline { 3 - 5 } & Evaluation Methods & $48(96 \%)$ \\
\hline Outputs & Trained teacher in & Teaching material & $38(76 \%)$ \\
\cline { 3 - 5 } & $\begin{array}{l}\text { using Electronic } \\
\text { course based on } \\
\text { learning outcomes in } \\
\text { polynomial functions }\end{array}$ & $30(60 \%)$ \\
\cline { 3 - 5 } & Teaching Methods & $33(66 \%)$ \\
\cline { 3 - 5 } & Evaluation Methods & $48(96 \%)$ \\
\hline
\end{tabular}

Note. The percentage $=($ No. of narratives $/ 50)$ 
As shown in the tables above, the total number of responses was 2318 out of 2900 which means that the total percentage of responses was $80 \%$, indicating the validity of these themes to be constituents of a teaching model based on the system approach. The domains of the model achieved significant percentages of responses ranging 73-85\%, with the domain of evaluation methods achieving the highest percentage while the student's domain achieved the lowest percentage.

Table 9: The Responses to Ordering the LOSA Model Domains

\begin{tabular}{|l|l|l|l|l|l|l|}
\hline \multirow{2}{*}{ Domain } & \multicolumn{6}{|l|}{ No. of responses in each order (out of 50) } \\
\cline { 2 - 8 } & First & Second & Third & Fourth & Fifth & Sixth \\
\hline $\begin{array}{l}\text { Mathematical } \\
\text { content }\end{array}$ & 32 & 6 & 4 & 0 & 6 & 2 \\
\hline Teachers & 5 & 6 & 4 & 6 & 4 & 25 \\
\hline $\begin{array}{l}\text { Evaluation } \\
\text { Methods }\end{array}$ & 6 & 5 & 1 & 24 & 2 & 12 \\
\hline Equipment & 1 & 33 & 9 & 2 & 3 & 2 \\
\hline Student & 1 & 0 & 4 & 12 & 31 & 2 \\
\hline Teaching methods & 5 & 0 & 28 & 6 & 4 & 7 \\
\hline
\end{tabular}

Note. Number of responses in each order (out of 50)

Table 9 above indicates that the mathematical content domain ranked first whereas the equipment; the teaching methods; the evaluation methods; the students; and the teachers came in second, third, fourth, fifth and sixth respectively.

\subsection{Quantitative Results}

Table 10 below shows the average for the responses of forty-three education technology specialists to a questionnaire evaluating the electronic guide of the teaching model. The eight-item, 0-10-rating questionnaire was created based on the standards for evaluating electronic resources of Singh (2003).

Table 10: Means and Standard Deviation of Evaluator of Electronic Procedural Guide for the LOSA Model

\begin{tabular}{|l|l|l|l|}
\hline Dimension & Mean & Std. Deviation & Variance \\
\hline Purpose & 7.98 & 1.83 & 3.36 \\
\hline Authority & 7.85 & 1.23 & 1.52 \\
\hline Accuracy and Currency & 8.14 & 0.73 & 0.54 \\
\hline Objectivity & 8.43 & 1.11 & 1.22 \\
\hline Reliability & 8.42 & 0.89 & 0.79 \\
\hline
\end{tabular}




\begin{tabular}{|l|l|l|l|}
\hline Coverage & 7.92 & 1.05 & 1.10 \\
\hline Format and Presentation & 8.14 & 0.68 & 0.46 \\
\hline Special features & 8.24 & 0.85 & 0.73 \\
\hline Overall & 8.16 & 0.32 & 0.10 \\
\hline
\end{tabular}

The results in Table 10 above show that the overall average of the responses to evaluating the electronic guide was 8.16. The guide scored 7.85-8.43 in all evaluation fields with the (authority) filed getting the highest score while the (objectivity) filed scoring lowest. These scores corroborate the electronic procedural guide's suitability to be used.

\section{Discussion}

Characteristics of the LOSA Model: It is worth noting that the model is inclusive of all elements of the learning/teaching process (Tan, 2017), throughout its six domains, covering the pre-teaching, during teaching, and post-teaching stages. In addition, the model consists of several systems that integrate and interact to yield the outputs. On the one hand, there is an internal system of inputs functioning within the overall system of the model. On the other hand, there is an interactive relation between the constituents of each domain (inputs, processes, and outputs) and between the domains themselves. Flexibility is another trait of the model as it allows the improvement and modification of the preliminary outputs in order to reach the targeted final outputs.

Responses to the Supporting Electronic Course on Blackboard: As for the designing of the model, the responses of the experts were lowest when it came to the supporting electronic course on Blackboard under the mathematical content, the students, and the teacher's domains, ranging from $60-62 \%$. This was due to the small number of information technology specialists within the study sample compared to the other participants. This lower ranking of the electronic course prevented it from being the main and alternative learning resource. Instead, it was employed as a technological solution serving two purposes: offering additional learning opportunities for the students who did not achieve the learning outcome(s) in the classroom (Singh, 2003) as well as providing forums on Blackboard for students to exchange knowledge whereby the students who failed to achieve a certain outcome(s) can communicate with their outcomeachieving classmates.

Responses to the Equipment Domain: In the equipment domain, responses to the traditional classroom/lab as an input were at a low $60 \%$. This is understandable as it shows the experts' conviction that the traditional classroom/lab is unsuitable as Viji \& Raja (2017) said, and has to be specially prepared, for learning and teaching outcomes. After processing the classrooms/labs into usable outputs, the responses were at a maximum $100 \%$. 
Responses to the Teaching Methods Domain: The domain of the teaching methods had the highest percentage of responses, $98 \%$, in the field of 'teaching using groups', whether as inputs or outputs. This fit with the believes of Gupta (2013) that teaching outcomes based on the system approach depends greatly on students themselves working together to exchange and bridge any gaps in knowledge. On the other hand, in the teacher's domain, the responses to the field of 'teaching methods training' were lower at $66 \%$. Seemingly contradictory, this is because the responses related to teaching methods as processes and outputs were not limited to 'teaching using groups;' rather, they also covered 'traditional teaching' and 'teaching using the electronic course,' and because these two fields had low responses, they affected the overall percentage.

Responses to Initial Evaluation: The lowest percentage of $66 \%$ was that of the initial evaluation. This reflects the experts' point of view that designing the mathematical content with exercises on the prerequisites of each outcome is almost sufficient enough to bridge any gaps in the prerequisites (Lallemand, 2018). However, the initial evaluation remains significant in assessing each student's knowledge of the prerequisites; it saves effort and enables the students to help each other based on the outcome(s) they did or did not achieve (National Council of Teachers of Mathematics (NCTM, 2000).

Responses to the LOSA Model as a Whole Structure: After analyzing the responses to the model as a whole structure with inputs, processes, and outputs, it can be seen that the lowest responses were to the processes stage with $70-80 \%$. This can be attributed to the numerous details involved in the processes as it is the stage that handles the procedures. As a result, the responses were varying and unfocused, and this was one of the main reasons that led the researcher to design the model by identifying the procedural mechanisms and transforming them into an electronic procedural guide that facilitates using the model in the classroom.

Responses to the Evaluation of the Electronic Procedural Guide: The responses of the education technology experts to the evaluative form designed by Singh (2003) for the electronic procedural guide were very good because the guide was already tested by information technology specialists whose feedback was utilized in making the necessary modifications. Furthermore, the evaluators thought that the guide was essential in making the model practical and userfriendly.

\section{Conclusion and Suggestions}

This study provides a model for teaching the learning outcomes of polynomial functions, consisting of six domains: the mathematical content; the equipment; the teaching methods; the evaluation methods; the students; and the teachers. In each domain, the inputs were processed to produce the required outputs through a procedural method based on the system approach. In addition, the study provides an electronic procedural guide that shows precisely how to use each and every constituent of the model. It also provides the outputs of the model which are its usable tools as a teaching model. These outputs are the 
learning outcomes and their prerequisites; the mathematical content of polynomial functions; the supporting electronic content on Blackboard; the initial, formative, and summative evaluation tools; the mechanisms for preparing the equipment; the teaching methods; and the training methods that qualify the students and teachers to work with the model. It is worth noting that in the second part of this project, the researcher applied the model to a sample of students to verify its effectiveness in helping the learners acquire the standards for the mathematical content of polynomial functions according to NCTM (2000)

\section{Recommendations}

The researcher recommends the following:

1- Redesigning all units of the College Algebra course according to the model.

2- Expanding the model to be suitable for broader areas such as academic programs and courses.

3-Conducting studies that seek creating mechanisms and standards for classifying students according to their achievement of learning outcomes at all levels: textbook unit, course, or academic program.

\section{Limitations}

Geographical Limitations: The University of Jordan, Middle East University, and Amman Arab University according to the official approvals that were attained to implement the study.

Time Limitations: the study was implemented during the 2018-2019 academic year.

Content Limitations: the mathematical content chosen for the model was the polynomial functions unit of the College Algebra course taught for high schoollevel / pre-university students.

Conflict of Interest: No Conflict of interest has been declared by the author.

Acknowledgements: The author is grateful to the Middle East University, Amman, Jordan for the financial support granted to cover the publication fee of this research article.

\section{References}

Ackoff, R. L. (1971). Towards a system of systems concepts. Management science, 17(11), 661-671.

Adam, S. (2006). An introduction to learning outcomes: A consideration of the nature, function and position of learning outcomes in the creation of the European Higher Education Area. Article B. 2.3-1. EUA Bologna Handbook.

Alexandrov, N., \& Sancho, M.-R. (2017). Learning outcomes based evaluation of HPC professional training. Procedia Computer Science, 108, 2141-2150. http://doi.org/10.1016/j.procs.2017.05.135

Amalia, E., Surya, E., \& Syahputra, E. (2017). The effectiveness of using problem based learning (PBL) in mathematics problem solving ability for junior high school 
students. International Journal of Advance Research and Innovative Ideas in Education, 3(2). http://doi.org/16.0415/IJARIIE-4659

Barkley, E. F., \& Major, C. H. (2020). Student engagement techniques: A handbook for college faculty: John Wiley \& Sons.

Bloom, B. S. (1956). Taxonomy of educational objectives, handbook I: the cognitive domain. New York: David McKay Co: Inc.

Clements, D. H., Fuson, K. C., \& Sarama, J. (2017). The research-based balance in early childhood mathematics: A response to Common Core criticisms. Early Childhood Research Quarterly, 40, 150-162. http://doi.org/10.1016/j.ecresq.2017.03.005

Curto Prieto, M., Orcos Palma, L., Blázquez Tobías, P. J., \& León, F. J. M. (2019). Student assessment of the use of Kahoot in the learning process of science and $\begin{array}{llll}\text { mathematics. } & \text { Education } & \text { Sciences, } & \end{array}$ http://doi.org/10.3390/educsci9010055

Darling-Hammond, L. (2017). Teacher education around the world: What can we learn from international practice? European Journal of Teacher Education, 40(3), 291-309. http://doi.org/10.1080/02619768.2017.1315399

DuPlass, J. A. (2006). Middle and high school teaching: Methods, standards, and best practices. Houghton Mifflin Company Boston.

Eviyanti, C. Y., Surya, E., Syahputra, E., \& Simbolon, M. (2017). Improving the students' mathematical problem solving ability by applying problem based learning model in VII grade at SMPN 1 Banda Aceh Indonesia. International Journal of Novel Research in Education and Learning, 4(2), 138-144.

Gudeva, L. K., Dimova, V., Daskalovska, N., \& Trajkova, F. (2012). Designing descriptors of learning outcomes for Higher Education qualification. Procedia-Social and Behavioral Sciences, 46, 1306-1311. http:// doi.org/10.1016/j.sbspro.2012.05.292

Gupta, S., \& Gupta, A. (2013). The systems approach in education. International Journal of Management, 1(1), 52-55.

Hasibuan, A. M., Saragih, S., \& Amry, Z. (2018). Development of learning materials based on realistic mathematics education to improve problem solving ability and student learning independence. International Electronic Journal of Mathematics Education, 14(1), 243-252. http://doi.org/10.29333/iejme/4000

Hofer, M., \& Harris, J. (2019). Topics \& Sequences in Experienced Teachers' Instructional Planning for Technology Integration. Research Highlights in Technology and Teacher Education 2019, 35.

Isdale, K., Reddy, V., Juan, A., \& Arends, F. (2018). TIMSS 2015 Grade 5 national report: Understanding mathematics achievement amongst Grade 5 learners in South Africa: Nurturing green shoots.

Kitchen, R., \& Berk, S. (2016). Educational technology: An equity challenge to the Common Core. Journal for Research in Mathematics Education, 47(1), 3-16. http://doi.org/10.5951/jresematheduc.47.1.0003

Kizilcec, R. F., Pérez-Sanagustín, M., \& Maldonado, J. J. (2017). Self-regulated learning strategies predict learner behavior and goal attainment in Massive Open Online Courses. Computers \& education, 104, 18-33. http://doi.org/10.1016/j.compedu.2016.10.001

Korhonen, A. M., Ruhalahti, S., \& Veermans, M. (2019). The online learning process and scaffolding in student teachers' personal learning environments. Education and Information Technologies, 24(1), 755-779. http:// doi.org/10.1007/s10639-018-97934 
Lallemand, C. (2018). Conciliating scientific requirements and relevance to practice: why is it such a dilemma for the development of UX design and evaluation methods? UK: University of Nottingham.

Lamb, R. L., Annetta, L., Firestone, J., \& Etopio, E. (2018). A meta-analysis with examination of moderators of student cognition, affect, and learning outcomes while using serious educational games, serious games, and simulations.

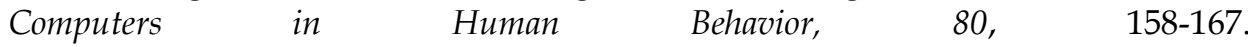
http://doi.org/10.1016/j.chb.2017.10.040

Mat, S., Yassin, R. M., Ishak, N., Mohammad, N., \& Pandaragan, S. L. (2012). Model of problem-based learning using systems approach. Procedia-Social and Behavioral Sciences, 60, 541-545. http://doi.org/10.1016/j.sbspro.2012.09.420

Murtonen, M., Gruber, H., \& Lehtinen, E. (2017). The return of behaviourist epistemology: A review of learning outcomes studies. Educational Research Review, 22, 114-128. http://doi.org/10.1016/j.edurev.2017.08.001

Naja, A. R. (2018). Analysis of students' creative thinking level in problem solving based on national council of teachers of mathematics. Paper presented at the Journal of Physics: Conference Series.

Oudman, S., van de Pol, J., Bakker, A., Moerbeek, M., \& van Gog, T. (2018). Effects of different cue types on the accuracy of primary school teachers' judgments of students' mathematical understanding. Teaching and Teacher Education, 76, 214226. http:// doi.org/10.1016/j.tate.2018.02.007

Rodríguez, G., Pérez, J., Cueva, S., \& Torres, R. (2017). A framework for improving web accessibility and usability of Open Course Ware sites. Computers $\mathcal{E}$ education, 109, 197-215. http://doi.org/10.1016/j.compedu.2017.02.013

Ross, J. G., Bruderle, E., \& Meakim, C. (2015). Integration of deliberate practice and peer mentoring to enhance students' mastery and retention of essential skills. Journal of Nursing Education. 54(3), 52-54. http:// doi.org/10.3928/01484834-20150218-20

Rothaermel, F. T. (2016). Strategic management: concepts (Vol. 2). McGraw-Hill Education.

Sari, N., \& Surya, E. (2017). Analysis effectiveness of using problem posing model in mathematical learning. International Journal of Sciences: Basic and Applied Research (IJSBAR), 33(3), 13-21.

Singh, S. (2003). Evaluation of electronic reference sources. DESIDOC Journal of Library $\mathcal{E}$ Information Technology, 23(2).

Sinha, S. (2018). Fundamentals of Education. Lulu.com.

Stelmach, B., Adams, P., \& Brandon, J. (2019). A Literature Synthesis: Optimum Learning for All Students--Implementation of Alberta's 2018 Professional Practice Standards.

Tan, P. (2017). Advancing Inclusive Mathematics Education: Strategies and Resources for Effective IEP Practices. International Journal of Whole Schooling, 13(3), 28-38.

Taylor, R. D., Oberle, E., Durlak, J. A., \& Weissberg, R. P. (2017). Promoting positive youth development through school-based social and emotional learning interventions: A meta-analysis of follow-up effects. Child development, 88(4), 1156-1171. http://doi.org/10.1111/cdev.12864

Tractenberg, R. E., Lindvall, J. M., Attwood, T., \& Via, A. (2020). Guidelines for curriculum and course development in higher education and training. http://doi.org/10.31235/osf.io/7qeht

Viji, B., \& Raja, B. W. D. (2017). Preparing Teachers for Multisensory Teaching Strategy to Improve the Learning Outcomes of Students with Reading Disabilities. The Journal, 58. 
Webb, S., Massey, D., Goggans, M., \& Flajole, K. (2019). Thirty-five years of the gradual release of responsibility: scaffolding toward complex and responsive teaching. The Reading Teacher, 73(1), 75-83. http:// doi.org/10.1002/trtr.1799

Wilson, J. (2020). Reflections on Mathematics Education Research: 1970-1982. Journal for Research in Mathematics Education, 51(1), 3-11. http://doi.org/10.5951/jresematheduc.2019.0004 